\title{
KAJIAN BAGI HASIL DAN PENDAPATAN PETANI BERBASIS KOMODITI DI DESA ERELEMBANG KECAMATAN TOMBOLOPAO KABUPATEN GOWA
}

\author{
(Study Profit Sharing And Income Of Commodity Based Farmer In Erelembang Village, \\ Tombolopao District, Gowa District) \\ Ardi Rumallang \\ Prodi Agribisnis Fakultas Pertanian Universitas Muhammadiyah Makassar \\ Email. ardi.rumallang@unismuh.ac.id
}

Article Submitted : 01-08-2019

Article Accepted : 03-10-2019

\begin{abstract}
This research aim to know and analyze profit sharing system, income and efficiency of commodity based farming in Erelembang Village Tombolopao District Gowa Regency. Population and sample in this research is all farmers who do commodity based sharing. The number of samples in this study were 50 people using random sampling technique. Data used in this research are primary data and secondary data. The analysis used in this research is descriptive qualitative analysis, income analysis, with the formula $\mathrm{I}=\mathrm{TR}-\mathrm{TC}$ and $\mathrm{R} / \mathrm{C}$ ratio analysis. The results showed that the profit-sharing system based on the commodity in Erelembang Village is a system for three or 3: 1 and a system for two or two: 1. The income level of the owner farmer is greater than the income of the farmers and the commodity based farming in the research location including efficient
\end{abstract}

Keywords: Profit Sharing, Income, efficiency and farming

\section{PENDAHULUAN}

Komoditas tanaman hortikultura adalah salah satu tanaman yang sangat penting dan strategis kedudukannya sebagai sumber penyediaan kebutuhan pangan pokok yaitu berupa sayur mayur. Sayur mayur berkaitan erat dengan kebutuhan rakyat banyak dan dapat dijadikan sebagai alat politik. Jumlah penduduk yang semakin meningkat menyebabkan kebutuhan akan sayur mayor pun semakin meningkat. Namun, produksi sayur mayur cenderung stagnan bahkan menurun dan kondisi kesejahteraan petani itu sendiri juga terus mengalami penurunan (Mariyah, 2008).

Dalam tatanan pertanian pedesaan, secara garis besar sistem penguasaan lahan dapat diklasifikasikan statusnya menjadi hak milik, sewa, sakap (bagi hasil), dan gadai. Status hak milik adalah lahan yang dikuasai dan dimiliki oleh perorangan atau kelompok atau lembaga/organisasi. Pakpahan (1992) dalam Irmayanti (2010) mengemukakan bahwa status sewa, sakap (bagi hasil), dan gadai adalah bentukbentuk penguasaan lahan dimana terjadi pengalihan hak garap dari pemilik lahan kepada orang lain. Bentuk kelembagaan ini sudah menjadi bagian dari tatanan masyarakat pedesaan dimana keberadaannya bersifat dinamis antar ruang dan waktu. Jadi terlihat bahwa lahan merupakan faktor produksi utama dalam usaha pertanian. Dengan kata lain, eksistensi lahan dapat digarap sebagai tumpuan dalam produksi usahatani yang dapat mendatangkan kesempatan kerja dan perolehan imbalan (pendapatan).

Suatu usahatani yang dilaksanakan secara terpadu pada dasarnya adalah untuk meningkatkan pendapatan petani agar dapat menghidupi seluruh keluarganya 
sekaligus meningkatkan kesejahteraan petani tersebut (Mubiyarto, dalam Isyanto, 2012). Tujuan petani dalam melaksanakan usahataninya adalah untuk memperoleh produksi yang tinggi dengan biaya yang rendah (Adilaga dalam Isyanto, 2012).

Menurut Soekartawi (1995), pendapatan merupakan selisih antara penerimaan dan semua biaya. Biaya memegang peranan yang sangat penting untuk dibandingkan dengan pendapatan yang akan diperoleh. Selain itu lembaga pemasaran juga berperan didalam menyalurkan hasil produksi petani yang berpengaruh pada tingkat harga yang akan diterima oleh petani. Mosher, Dalam Isyanto, (2012) menyatakan, bahwa peningkatan pendapatan akan diperoleh bukan saja oleh pengetahuan bercocok tanam saja, tetapi juga ditentukan oleh pembiayaan, pemasaran dan kepandaian petani dalam menggunakan faktor-faktor produksi yang sangat terbatas jumlahnya.

Mardikanto dalam Isyanto, (2012) juga menyatakan, bahwa rendahnya pendapatan petani disebabkan oleh: 1). Sempitnya luas lahan usahatani yang dimiliki, 2). Rendahnya produktivitas usahatani karena keterbatasan peralatan dan teknologi yang diterapkan serta keterbatasan petani kecil untuk menggunakan inputinput modern (seperti: benih, pupuk buatan dan pestisida), 3). Sistem pemasaran yang seringkali tidak menguntungkan petani kecil dan 4). Keterbatasan penghasilan dari sektor lain karena rendahnya pendidikan dan ketrampilan yang dimilikinya.

Berbicara tentang pendapatan berarti penghasilan yang diterima oleh seorang individu, daerah maupun negara dari semua kegiatan yang dilakukan. Pendapatan bagi seseorang sangat penting artinya karena dengan pendapatan yang dimilikinya maka seseorang dapat memenuhi kebutuhan sekunder dalam mencapai tingkat kepuasan maksimal.

Di daerah penelitian yakni di Desa Erelembang Kecamatan Tombolopao
Kabupaten Gowa, banyak petani yang mengusahakan tanaman pertanian berbasis komoditi, dimana status penguasaan lahan yang berbeda yakni petani yang mengolah atau menggarap lahan sendiri (petani pemilik penggarap), petani yang menggarap lahan orang lain dengan sistem bagi hasil (petani penyakap), petani yang menyewa lahan orang lain dan petani yang tinggal di desa lain tetapi memiliki dan menggarap lahan didaerah penelitian. Namun yang menjadi perhatian utama dalam penelitian ini adalah petani pemilik penggarap dan petani penyakap. Dalam perbedaan sistem kepemilikan lahan ini tentunya akan menimbulkan perbedaan dalam penerimaan petani. Selain itu tingkat pendapatan dan tingkat efisiensi pada usahatani mereka juga akan berbeda pula.

Bagi hasil merupakan salah satu sarana tolong menolong bagi sesama manusia dalam memenuhi kebutuhan hidupnya. Pihak yang mempunyai lahan menyerahkan lahannya kepada pihak petani atau penggarap untuk diusahakan sebagai lahan yang menghasilkan, sehingga pihak pemilik lahan dapat menikmati dari hasil lahannya, dan petani yang sebelumnya tidak memiliki lahan untuk bercocok tanam juga dapat berusaha serta dapat memperoleh hasil yang sama dari lahan tersebut.

\section{METODE PENELITIAN}

Penelitian ini dilaksanakan di Desa Erelembang Kecamatan Tombolopao Kabupaten Gowa. Penelitian ini dilakukan selama 4 bulan mulai bulan Juli sampai Oktober 2017. Populasi dan sampel dalam penelitian ini adalah seluruh petani yang melakukan usahatani berbagai macam komoditi (pemilik penggarap, petani penyakap) yang ada di daerah penelitian. Jumlah sampel dalam penelitian ini sebanyak 50 orang dengan menggunakan teknik random sampling

Data yang digunakan dalam penelitian ini adalah data sekunder yang dipublikasikan oleh Badan Pusat Statistik 
(BPS) dan Instansi Pemerintah terkait lainnya, dan data primer yang diperoleh langsung dari responden.

Untuk menganalisa sistem bagi hasil berbasis komoditi digunakan deskriptif kualitatif yaitu menjelaskan secara trasnparan dan mendalam terkait sistem bagi hasil dilokasi penelitian.

Untuk menganalisis berapa tingkat pendapatan petani pemilik penggarap dan petani penyakap digunakan rumus sebagai berikut:

$$
\mathbf{I}=\mathbf{T R}-\mathbf{T C}
$$

Dimana :

I = Income (Pendapatan)

$\mathrm{TR}=$ Total Renue (Penerimaan)

$\mathrm{TC}=$ Total Cost (Total Biaya)

Untuk menganalisis tingkat efisiensi usahatani berbasis komoditi digunakan rumus:

Total revenue (TR)

$\mathrm{R} / \mathrm{C}$ Ratio $=$

Total cost (TC)

Dimana $: \mathrm{TR}=$ Total revenue

$\mathrm{TC}=$ Total cost

Dengan kriteria :

1. Jikan nilai $\mathrm{R} / \mathrm{C}$ ratio $<1$, maka usahatani berbasis komoditi yang diusahakan tidak efeisien

2. Jika nilai $\mathrm{R} / \mathrm{C}$ ratio $>1$, maka usahatani berbasis komoditi yang diusahakan telah efisien

3. Jika nillai $\mathrm{R} / \mathrm{C}$ ratio $=1$, maka usahatani berbasis komoditi yang diusahakan belum efisien karena tidak menguntungkan.

Untuk menganalisis perbedaan pendapatan petani pemilik penggarap dan petani penyakap berbasis komoditi dilakukan analisis uji beda pendapatan.

\section{HASIL DAN PEMBAHASAN}

\section{Kajian Bagi Hasil Berbasis Komoditi}

Bagi hasil berbasis komoditi di Desa Erelembang pada hakikatnya merupakan kesepakatan bersama antara petani pemodal dengan petani penggarap yang sifatnya tersirat. Kesepakatan itu terjadi turun temurun dari nenek moyang semenjak mengenal usahatani sampai sekarang. Bagi hasil berbasis komoditi yang dimaksud adalah bagi hasil ushatani kentang, usahatani kubis, usahatani tomat dan usaha tani sawi.

\section{Bagi Hasil Usahatani Kentang}

Bagi hasil usahatani kentang di Desa Erelembang Kecamatan Tombolopao Kabupaten Gowa mulai dikenal sekitar tahun 1990 an. Masyarakat mengenal usahatani kentang diawali dengan adanya penduduk jawa yang datang ke desa tersebut melakukan budidaya kentang. Melihat bahwa usahatani kentang pada saat itu menjanjikan dalam memenuhi kebutuhan dan kesejahteraan mereka maka masyarakat memulai menanam kentang walaupun dalam skala kecil/ skala rumah tangga. Seiring berjalannya waktu kebutuhan akan komoditi kentang terus meningkat baik kebutuhan pangan rumah tangga maupun kebutuhan industri maka usahatani kentang terus dikembangkan sampai sekarang. Melihat usahatani kentang yang begitu menjanjikan, sehingga masyarakat Desa Erelembang khususnya Dusun Biringpanting menjadikan usahatani kentang sebagai usaha pokok dalam berusahatani.

Bagi hasil usahatani kentang di Desa Erelembang terjadi karena adanya starata sosial dan ekonomi yang dimiliki berbeda. Strata sosial dan ekonomi yang dimaksud adalah perbedaan dalam hal pendidikan, dan penguasaan / kepemilikan lahan masyarakat. Petani yang berpendidikan sarjana dan memiliki lahan melakukan usahatani dengan memanfaatkan petani lain yang berpendidikan rendah yang tidak memiliki lahan mengelolah lahan mereka untuk ditanami kentang. Hasil dari usahatani kentang tersebut dibagi sesuai dengan hasil yang telah disepakati dan berlaku umum di masyarakat.

Pembagian hasil produksi kentang dilakukan dengan istilah "bagi tiga" atau dengan $3: 1$. Arti dari istilah tersebut adalah hasil produksi kentang dibagi menjadi: 
a. 2 bagian milik petani pemodal dan pemilik lahan

b. 1 bagian milik petani pekerja atau penyakap

Secara kuantitas bagi hasil usahatani kentang dapat dijelaskan ketika di asumsikan bahwa dalam satu kali periode produksi mendapatkan penerimaan Rp. 1.500 .000 maka Rp. 1.000 .000 milik petani pemodal dan pemilik lahan Rp. 500.000 milik petani pekerja atau penyakap.

\section{Bagi Hasil Usahatani Kubis}

Usahatani kubis di Desa Erelembang mulai dikenal masyarakat hampir bersamaan dengan dikenalnya usahatani kentang. Bagi hasil usahatani kubis di Desa Erelembang dikenal dengan istilah " bagi dua" atau dengan kata lain 2: 1 yang secara umum dikenal dimasyarakat luas 50 : 50. Hasil produksi kubis dibagi menjadi:

a. 1 bagian milik pemodal dan pemilik lahan a. 1 bagian petani penggarap atau pekerja

Secara kuantitas bagi hasil usahatani kubis dapat dijelaskan ketika di asumsikan bahwa dalam satu kali periode produksi mendapatkan penerimaan Rp. 1.00.000 maka Rp. 500.000 milik petani pemodal dan pemilik lahan Rp. 500.000 milik petani pekerja atau penggarap.

\section{Bagi hasil Ushatani Tomat}

Bagi hasil usahatani tomat di Desa Erelembang pada hakikatnya sama dengan bagi hasil usahatani kentang. Bagi hasil usahatani tomat dikenal dengan istilah "bagi tiga" atau dengan 3 : 1. Arti dari istilah tersebut adalah hasil produksi tomat dibagi menjadi:

a. 2 bagian milik petani pemodal dan pemilik lahan

b. 1 bagian milik petani pekerja atau penyakap

Secara kuantitas bagi hasil usahatani kentang dapat dijelaskan ketika di asumsikan bahwa dalam satu kali periode produksi mendapatkan penerimaan Rp. 1.500 .000 maka Rp. 1.000 .000 milik petani pemodal dan pemilik lahan $\quad$ Rp. 500.000 milik petani pekerja atau penyakap.

\section{Bagi hasil Ushatani Sawi}

Bagi hasil usahatani sawi di Desa Erelembang pada hakikatnya sama dengan sistem bagi hasil kubis. Bagi hasil usahatani sawi di Desa Erelembang dikenal dengan istilah " bagi dua" atau dengan kata lain $2: 1$ yang secara umum dikenal dimasyarakat luas $50: 50$. Hasil produksi sawi dibagi menjadi:

b. 1 bagian milik pemodal dan pemilik lahan b. 1 bagian petani penggarap atau pekerja

Secara kuantitas bagi hasil usahatani sawi dapat dijelaskan ketika di asumsikan bahwa dalam satu kali periode produksi mendapatkan penerimaan Rp. 1.00.000 maka Rp. 500.000 milik petani pemodal dan pemilik lahan Rp. 500.000 milik petani pekerja atau penggarap.

Bagi Hasil Usahatani Berbasis Komoditi

Bagi hasil usahatani berbasis komoditi di desa erelembang kecamatan Tombolopao Kabupaten Gowa dapat dilihat pada Tabel berikut ini.

Tabel 1. Sistem Bagi Hasil Berbasis Komoditi di Desa Erelembang Kecamatan Tombolopao Kabupaten Gowa, 2017

\begin{tabular}{clcl}
\hline No & \multicolumn{1}{c}{ Komoditi } & Sistem & Istilah \\
\hline 1 & Kentang & $3: 1$ & Bagi tiga \\
2 & Kubis & $2: 1$ & Bagi dua \\
3 & Tomat & $3: 1$ & Bagi tiga \\
4 & Sawi & $2: 1$ & Bagi dua \\
\hline
\end{tabular}

Sumber: Data Primer Setelah Diolah, 2017

Tabel 1 menunjukkan bahwa terjadi perbedaan dalam sistem bagi hasil berbasis komoditi di Desa Erelembang. Tabel tersebut menunjukkan bahwa bagi hasil usahatani 
kentang sama dengan usahatani tomat, sedangkan bagi hasil usahatani kubis sama dengan usahatani sawi. Selain itu, menunjukkan bahwa petani pemodal dan pemilik lahan mendapatkan bagian lebih banyak dibandingkan dengan petani penggarap tergantung komoditi yang diusahakan.

Perbedaan bagian yang diterima antara petani pemilik lahan dan pemodal dengan petani penggarap itu disebabkan oleh persentase input dalam usahatani yang diusahakannya. Input yang dikeluarkan oleh petani pemilik modal dan pemilik lahan mulai dari awal usahatani sampai kepada produksi. Input yang dimaksud berupa: lahan, benih, pupuk kandang, pupuk kimia dan pestisida (Herbisida, Fungisida dan Insektisida). Sedangkan input dari petani penggarap hanya tenaga kerja yang dikeluarkan dalam berusahatani. Sehingga curahan input dari petani pemodal dan pemilik lahan dengan petani penggarap ketika dikonversi dalam nilai rupiah, maka petani pemilik modal dan pemilik lahan mengeluarkan biaya lebih besar dibandingkan dengan petani penggarap.

Disisi lain, bagi hasil dengan istilah "bagi tiga" dan "bagi dua" itu muncul dengan persentase input yang dikeluarkan oleh petani pemodal dan pemilik lahan. Komoditi kentang dan komodti tomat yang merupakan sistem bagi tiga itu disebabkan karena input dalam usahatani komoditi tersebut lebih besar dibandingkan dengan usahatani kubis dan sawi yang merupakan sistem bagi dua.
Sistem bagi hasil berbasis komoditi di Desa Erelembang mempunyai keuntungan dan risiko yang sama antara petani pemilik modal dan petani penggarap, artinya bahwa ketika pihak yang satu memperoleh keuntungan maka pihak yang lain juga memperoleh keuntungan. Begitupun sebaliknya, apabila petani pemilik modal mengalami risiko kerugian maka petani penggarap juga mengalami risiko kerugian. Sehingga dalam sistem bagi hasil berbasis komoditi di Desa Erelembang merupakan sistem bagi hasil yang adil.

\section{Biaya yang Dikeluarkan dalam Usahatani Berbasis Komoditi}

Pengeluaran petani adalah semua biaya yang dikeluarkan dalam proses produksi/usaha tani. Biaya produksi yang dikeluarkan terdiri dari biaya tetap dan biaya variabel. Biaya tetap adalah biaya yang jumlahnya tidak tergantung oleh kapsitas produksi pada usahatani. Biaya tetap meliputi biaya penyusutan peralatan produksi yaitu parang, cangkul, pompa mesin, hand traktor dan sprayer gendong, serta biaya pajak bumi dan bangunan (PBB). Sedangkan biaya variabel adalah biaya yang jumlahnya tergantung pada kapasitas produksi usaha tani.

\section{Biaya Usahatani Kentang}

Biaya usahatani kentang yang dikeluarkan dalam satu musim tanam sangat beragam. Tergantung dengan luas lahan yang dimiliki dan dikelolah oleh petani. Adapun jenis biaya yang di keluarkan dalam berusahatani kentang dapat dilihat pada Tabel 2 berikut ini:

Tabel 2. Jenis Biaya yang Dikeluarkan oleh Petani Kentang Responden per ha di Desa Erelembang Kecamatan Tombolopao Kabupaten Gowa, Tahun 2017.

\begin{tabular}{|c|c|c|c|}
\hline Jenis Biaya & $\begin{array}{l}\text { Jumlah } \\
\text { Satuan }\end{array}$ & $\begin{array}{c}\text { Harga } \\
\text { Satuan (Rp) }\end{array}$ & Total Biaya (Rp) \\
\hline \multicolumn{4}{|l|}{ 1. Biaya Variabel } \\
\hline - Bibit & $1.000 \mathrm{Kg}$ & 3.000 & 3.000 .000 \\
\hline - Pupuk Urea & $10 \mathrm{Zak}$ & 105.000 & 1.050 .000 \\
\hline - Pukuk Za & $5 \mathrm{Zak}$ & 95.000 & 475.000 \\
\hline - Pupuk Kandang & $300 \mathrm{Krng}$ & 6.5000 & 1.950 .000 \\
\hline
\end{tabular}




\begin{tabular}{|c|c|c|c|}
\hline - $\quad$ Pestisida & $30 \mathrm{Btl}$ & 30.000 & 900.000 \\
\hline - Pengolahan Tanah & 1 & 350.000 & 350.000 \\
\hline - Pembuatan Bedengan & 4 Hok & 30.000 & 120.000 \\
\hline - Pemupukan & 3 Hok & 30.000 & 90.000 \\
\hline - Penanaman & 7 Hok & 30.000 & 210.000 \\
\hline - Penviangan/pembumbungan & 14 Hok & 30.000 & 420.000 \\
\hline - Pemanenan & 20 Hok & 30.000 & 600.000 \\
\hline - гепl一anenan & 3 Hok & 30.000 & 90.000 \\
\hline \multirow{3}{*}{$\begin{array}{l}\text { 2. Biaya Tetap } \\
\text { - Penyusutan alat } \\
\text { - } \quad \text { Pajak }\end{array}$} & & & \\
\hline & - & 2.520 .000 & 2.520 .000 \\
\hline & 28.000 & 28.000 & 28.000 \\
\hline
\end{tabular}

Sumber : Data Primer Setelah Diolah, 2017

Tabel 2 menunjukkan bahwa petani responden dalam mengelolah dan mengeluarkan biaya per hektar maka harus menyediakan biaya sekitar Rp. 11.803.000. Dengan biaya sebesar ini yang dikeluarkan oleh petani per hektar maka petani diharapkan mempunyai manajemen pembiayaan yang dalam mengelola usaha taninya.

Pengeluaran petani kentang responden di lokasi penelitian bervariasi antara petani yang satu dengan petani yang lainnya. Perbedaan pengeluaran petani tergantung dari luas lahan yang dimiliki yang ditanami kentang, dosis pupuk yang diberikan, dan pemeliharaan yang dilakukan oleh petani responden.

\section{Biaya Usahatani Kubis}

Biaya usahatani kubis yang dikeluarkan dalam satu musim tanam sangat beragam. Tergantung dengan luas lahan yang dimiliki dan dikelolah oleh petani. Adapun jenis biaya yang di keluarkan dalam berusahatani kubis dapat dilihat pada Tabel 3 berikut ini:

Tabel 3. Jenis Biaya yang Dikeluarkan oleh Petani Kubis Responden per ha di Desa Erelembang Kecamatan Tombolopao Kabupaten Gowa, Tahun 2017.

\begin{tabular}{lcrr}
\hline \multicolumn{1}{c}{ Jenis Biaya } & Jumlah & \multicolumn{1}{c}{ Harga } & \multicolumn{2}{c}{ Total Biaya (Rp) } \\
& Satuan & Satuan (Rp) & \\
\hline 1. Biaya Variabel & & & 400.000 \\
- Bibit & 5 Bunkus & 80.000 & 735.000 \\
- Pupuk Urea & 7 Zak & 105.000 & 285.000 \\
- Pukuk Za & $3 \mathrm{Zak}$ & 95.000 & 1.950 .000 \\
- Pupuk Kandang & $300 \mathrm{Krng}$ & 6.500 & 600.000 \\
- Pestisida & $2 \mathrm{Btl}$ & 30.000 & 350.000 \\
- Pengolahan Tanah & 1 & 350.000 & 180.000 \\
- Pembuatan Bedengan & $6 \mathrm{Hok}$ & 30.000 & 150.000 \\
- Pemupukan & $5 \mathrm{Hok}$ & 30.000 & 210.000 \\
- Penanaman & $7 \mathrm{Hok}$ & 30.000 & 300.000 \\
- Penyiangan/pembumbungan & $10 \mathrm{Hok}$ & 30.000 & 450.000 \\
- Pemanenan & $15 \mathrm{Hok}$ & 30.000 & 1.250 .000 \\
\hline
\end{tabular}


2. Biaya Tetap

- Penyusutan alat

- Pajak
2.520 .000

28.000
2.520 .000

28.000

Total Biaya

9.408 .000

Sumber : Data Primer Setelah Diolah, 2017

Tabel 3 menunjukkan bahwa petani responden dalam mengelolah dan mengeluarkan biaya per hektar dalam usahatani kubis maka harus menyediakan biaya sekitar Rp. 9.408.000. Dengan biaya sebesar ini yang dikeluarkan oleh petani per hektar maka petani diharapkan mempunyai manajemen pembiayaan yang dalam mengelola usaha taninya.

Pengeluaran petani kubis responden di lokasi penelitian bervariasi antara petani yang satu dengan petani yang lainnya. Perbedaan pengeluaran petani tergantung dari luas lahan yang dimiliki yang ditanami kentang, dosis pupuk yang diberikan, dan pemeliharaan yang dilakukan oleh petani responden.

\section{Biaya Usahatani Tomat}

Biaya usahatani tomat yang dikeluarkan dalam satu musim tanam sangat beragam. Tergantung dengan luas lahan yang dimiliki dan dikelolah oleh petani. Adapun jenis biaya yang di keluarkan dalam berusahatani Tomat dapat dilihat pada Tabel 4 berikut ini:

Tabel 4. Jenis Biaya yang Dikeluarkan oleh Petani Tomat Responden per ha di Desa Erelembang Kecamatan Tombolopao Kabupaten Gowa, Tahun 2017.

\begin{tabular}{lcrr}
\hline \multicolumn{1}{c}{ Jenis Biaya } & Jumlah Satuan & $\begin{array}{c}\text { Harga Satuan } \\
(\mathrm{Rp})\end{array}$ & Total Biaya (Rp) \\
\hline 1. Biaya Variabel & & & \\
- Bibit & $10 \mathrm{Bunkus}$ & 180.000 & 1.800 .000 \\
- Pupuk Urea & $8 \mathrm{Zak}$ & 105.000 & 840.000 \\
- Pukuk Za & $5 \mathrm{Zak}$ & 95.000 & 475.000 \\
- Pupuk Kandang & $300 \mathrm{Krng}$ & 6.500 & 1.950 .000 \\
- Pestisida & $75 \mathrm{Btl}$ & 50.000 & 3.750 .000 \\
- Pengolahan Tanah & 1 & 350.000 & 350.000 \\
- Pembuatan Bedengan & $8 \mathrm{Hok}$ & 30.000 & 240.000 \\
- Pemupukan & $6 \mathrm{Hok}$ & 30.000 & 180.000 \\
- Penanaman & $7 \mathrm{Hok}$ & 30.000 & 210.000 \\
- Penyiangan/pembumbungan & $30 \mathrm{Hok}$ & 30.000 & 900.000 \\
- Pemanenan & $30 \mathrm{Hok}$ & 30.000 & 900.000 \\
- Tiang & $25 \mathrm{Hok}$ & 50.000 & 1.250 .000 \\
- Pengikatan & 10.000 & 1.000 & 10.000 .000 \\
2. Biaya Tetap & $50 \mathrm{Hok}$ & 50.000 & 2.500 .000 \\
- Penyusutan alat & & & \\
- Pajak & - & 2.520 .000 & 2.520 .000 \\
& 28.000 & 28.000 & 28.000 \\
\hline$\quad$ Total Biaya & & & \\
\hline
\end{tabular}


Tabel 4 menunjukkan bahwa petani responden dalam mengelolah dan mengeluarkan biaya per hektar dalam usahatani tomat maka harus menyediakan biaya sekitar Rp. 27.893.000. Dengan biaya sebesar ini yang dikeluarkan oleh petani per hektar maka petani diharapkan mempunyai manajemen pembiayaan yang dalam mengelola usaha taninya.

Pengeluaran petani tomat responden di lokasi penelitian bervariasi antara petani yang satu dengan petani yang lainnya. Perbedaan pengeluaran petani tergantung dari luas lahan yang dimiliki yang ditanami kentang, dosis pupuk yang diberikan, dan pemeliharaan yang dilakukan oleh petani responden.

\section{Biaya Usahatani Sawi}

Biaya usahatani sawi yang dikeluarkan dalam satu musim tanam sangat beragam. Tergantung dengan luas lahan yang dimiliki dan dikelolah oleh petani. Adapun jenis biaya yang di keluarkan dalam berusahatani Sawi dapat dilihat pada Tabel 5 berikut ini:

Tabel 5. Jenis Biaya yang Dikeluarkan oleh Petani Sawi Responden per ha di Desa Erelembang Kecamatan Tombolopao Kabupaten Gowa, Tahun 2017.

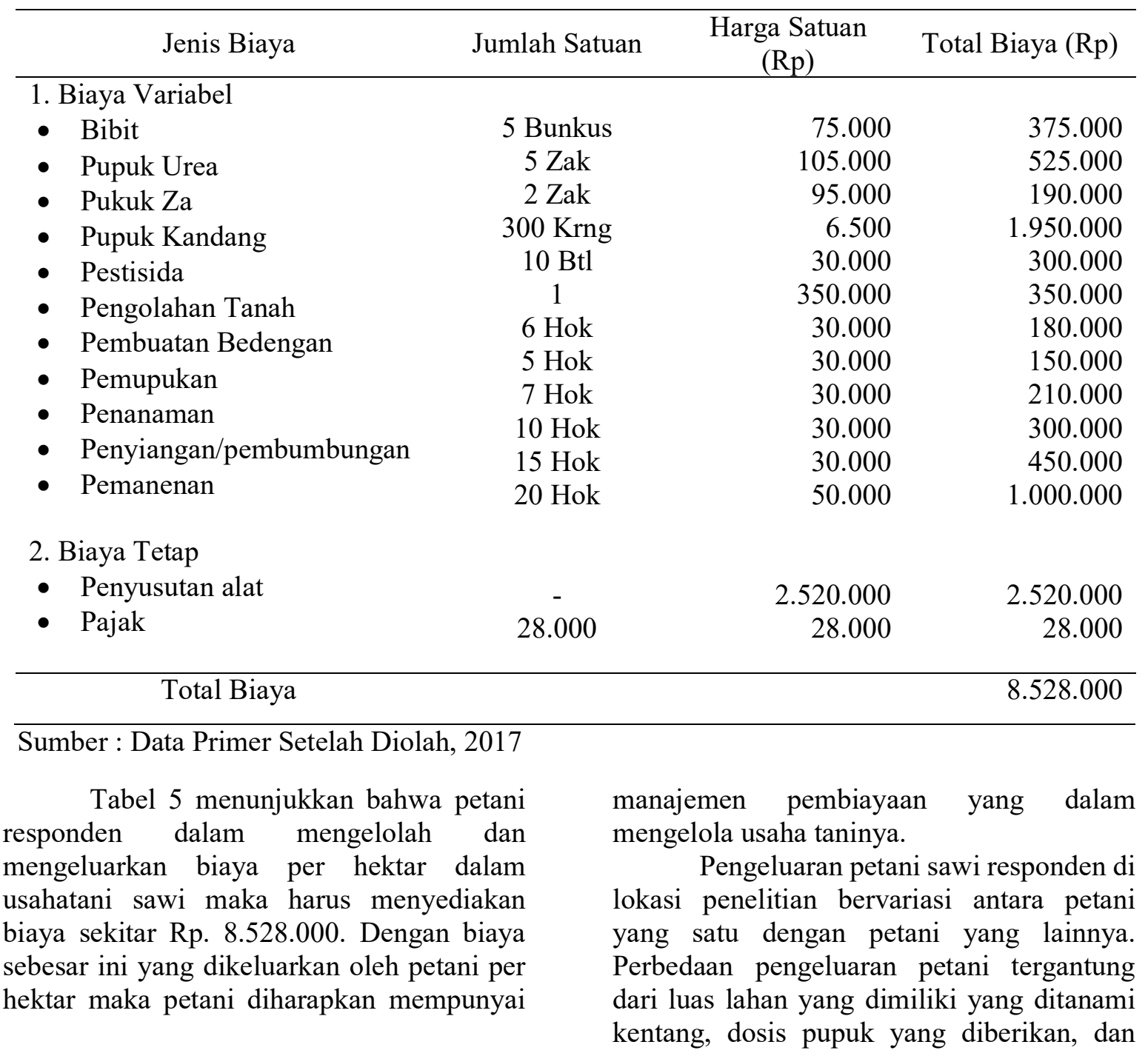


pemeliharaan yang dilakukan oleh petani responden.

\section{Produksi Usahatani Berbasis Komoditi}

Produksi berbasis komoditi di lokasi penelitian beravariasi. Produksi kentang, kubis, tomat dan sawi berbeda satu sama yang lain. Perbedaan produksi ini diakibatkan oleh berat masing-masing komoditi per buah atau biji yang dimiliki oleh komoditi tersebut. Perbedaan produksi dapat dilihat pada Tabel 6 berikut ini:

Tabel 6. Jumlah produksi komiditi per ha di Desa Erelembang Kecamatan Tombolopao Kabupaten Gowa, Tahun 2017

\begin{tabular}{ccc}
\hline No & Komoditi & Produksi $(\mathrm{Kg})$ \\
\hline 1 & Kentang & 12.000 \\
2 & Kubis & 14.000 \\
3 & Tomat & 16.000 \\
4 & Sawi & 10.000 \\
\hline
\end{tabular}

Sumber : Data Primer Setelah Diolah, 2017

Tabel 6 menunjukkan bahwa produksi komoditi di lokasi penelitian berbeda, dimana produksi kentang sebesar $12.000 \mathrm{Kg}$, produksi kubis sebesar $14.000 \mathrm{~kg}$, produksi tomat sebesar $26.000 \mathrm{~kg}$ dan produksi sawi sebesar $10.000 \mathrm{~kg}$

Pendapatan Petani berbasis komoditi
Pendapatan petani berbasis komoditi di lokasi penelitian berbeda antara komoditi yang satu dengan komoditi yang lain. Perbedaan ini disebabkan perbedaan produksi yang dihasilkan dan juga perbedaan harga pada saat produksi itu dijual. Untuk lebih jelasnya dapat dilihat pada Tabel 7 berikut ini:

Tabel 7. Pendapatan Petani berbasis komiditi per ha di Desa Erelembang Kecamatan Tombolopao Kabupaten Gowa, Tahun 2017

\begin{tabular}{ccccc}
\hline No & Komoditi & Produksi $(\mathrm{Kg})$ & Harga $(\mathrm{Rp})$ & Pendapatan $(\mathrm{Rp})$ \\
\hline 1 & Kentang & 12.000 & 11.000 & 132.000 .000 \\
2 & Kubis & 14.000 & 4.000 & 56.000 .000 \\
3 & Tomat & 16.000 & 12.500 & 200.000 .000 \\
4 & Sawi & 10.000 & 3.500 & 35.000 .000 \\
\hline
\end{tabular}

Sumber : Data Primer Setelah Diolah, 2017

Tabel 7 menunjukkan bahwa pendapatan petani responden berbasis komiditi berbeda. Perbedaan itu disebabkan komiditi yang diusahakan oleh petani responden. Dimana komoditi yang mendatangkan pendapatan tertinggi yaitu komoditi Tomat kemudian disusul komoditi kentang, kubis dan terakhir komoditi sawi.

\author{
Pendapatan Petani Pemilik dan Petani \\ Penggarap \\ Pendapatan petani pemilik dan petani \\ penggarap terjadi perbedaan. Perbedaan ini \\ diakibatkan oleh sistem bagi hasil yang telah \\ disepakati. Untuk lebih jelasnya dapat dilihat \\ pada tabel 8 berikut ini:
}


Tabel 8. Pendapatan Petani Pemilik dan Petani Penggarap di Desa Erelembang Kecamatan Tombolopao Kabupaten Gowa, Tahun 2017

\begin{tabular}{cccccc}
\hline No & Komoditi & Bagi hasil & $\begin{array}{c}\text { Pendapatan } \\
\text { sebelum dibagi } \\
(\mathrm{Rp})\end{array}$ & $\begin{array}{c}\text { Pendapatan } \\
\text { Petani Pemilik } \\
(\mathrm{Rp})\end{array}$ & $\begin{array}{c}\text { Pendapatan } \\
\text { petani } \\
\text { Penggarap (Rp) }\end{array}$ \\
\hline 1 & Kentang & $3: 1$ & 132.000 .000 & 88.000 .000 & 44.000 .000 \\
2 & Kubis & $2: 1$ & 56.000 .000 & 28.000 .000 & 28.000 .000 \\
3 & Tomat & $3: 1$ & 200.000 .000 & 133.200 .000 & 66.600 .000 \\
4 & Sawi & $2: 1$ & 35.000 .000 & 17.500 .000 & 17.500 .000 \\
\hline
\end{tabular}

Sumber : Data Primer Setelah Diolah, 2017

Tabel 8 menunjukkan bahwa pendapatan petani pemilik dan petani penggarap berbeda dari komoditi yang diusahakan. Untuk komodti kentang pendapatan petani pemilik sebesar Rp. 88.000.000 dan pendapatan petani penggarap sebesar Rp. 44.000.000, untuk komoditi kubis pendapatan petani pemilik dan petani penggarap sama yaitu sebesar $\mathrm{Rp}$. 28.000.000, untuk komoditi tomat pendapatan petani pemilik sebesar Rp. 133.200.000 dan pendapatan petani penggarap sebesar Rp. 66.600.000, sedangkan untuk komoditi sawi pendapatan petani pemilik dan petani penggarap sama yaitu sebesar Rp. 17.500.000.

\section{Efisiensi Usahtani Berbasis Komoditi}

Efisiensi Usahatani berbasis komoditi di lokasi penelitian berbeda antara komoditi yang satu dengan komoditi yang lain. Perbedaan ini disebabkan oleh jumlah biaya yang dikeluarkan masing-masing komoditi, jumlah produksi masing-masing komoditi dan harga masing-masing komoditi pada saat dijual. Untuk melihat perbedaan efisiensi dari masing-masing komoditi dapat dilihat pada tabel 9 berikut ini:

Tabel 9. Efisiensi Usahatani Berbasis Komoditi di Desa Erelembang Kecamatan Tombolopao Kabupaten Gowa, Tahun 2017

\begin{tabular}{ccccc}
\hline No & Komoditi & Biaya & Penerimaan(Rp) & Efisiensi \\
\hline 1 & Kentang & 11.803 .000 & 132.000 .000 & 111,84 \\
2 & Kubis & 9.408 .000 & 56.000 .000 & 5.95 \\
3 & Tomat & 27.893 .000 & 200.000 .000 & 7,71 \\
4 & Sawi & 8.528 .000 & 35.000 .000 & 4,10 \\
\hline
\end{tabular}

Sumber : Data Primer Setelah Diolah, 2017

Tabel 9 menunjukkan bahwa tingkat efisiensi masing-masing komoditi berbeda, dimana komoditi kentang mempunyai efisiensi terteinggi yaitu 111,84 kemudian disusul komoditi tomat 7,71 kemudian komoditi kubis 5,95 dan terakhir komoditi sawi 4,10. Melihat efisiensi dari semua komoditi yang diusahakan petani responden maka dapat disimpulkan bahwa usahatani berbasis komoditi dilokasi penelitian semuanya berada dalam kategori efisien.

\section{KESIMPULAN DAN SARAN}

\section{Kesimpulan}

Berdasarkan hasil dan pembahasan pada penelitian ini maka dapat diambil kesimpulan sebagai berikut:

1. Berdasarkan hasil penelitian yang dilakukan maka dapat dapat diambil kesimpulan, bahwa sistem bagi hasil berbasis komoditi di Desa Erelembang yaitu sistem bagi tiga atau $3: 1$ dan 
sistem bagi dua atau 2 : 1 yang merupakan sistem bagi hasil yang adil.

2. Tingkat pendapatan petani pemilik lebih besar daripada pendapatan petani penggarap dan usahatani berbasis komoditi di lokasi penelitian termasuk efisien.

\section{Saran}

Adapun saran penulis dalam penelitian ini adalah:

a. Kiranya sistem bagi hasil dalam berusahatani berbasis komoditi dipertahankan karena menguntungkan kedua belah pihak.

b. Kiranya sistem bagi hasil yang telah diterapkan dalam penelitian ini dijadikan acuan dalam usahatani yang lain.

\section{DAFTAR PUSTAKA}

Anonim, 2013. Pedoman Diversifikasi Tanaman Pangan. Ditjen Tanaman Pangan. Jakarta.

Arikunto, Suharsimi. $1996 . \quad$ Prosedur Penelitian Suatu PendekatanPraktek. Yogyakarta: Rineka Cipta.

Herveny, 2007. Ilmu Usahatani. Alumni, Bandung.

Irmayanti, 2010. Pola Penguasaan Lahan dan Reforma Agraria. Gramedia, Jakarta.

Isyanto, 2012. Faktor-Faktor yang Mempengaruhi Keputusan Tenaga
Kerja. Universitas Indonesia. Jakarta

Marsudi, 2011.Jurnal Dinamika Ekonomi Pembangunan. Juli 2011, Volume 1 Nomor 1. Jakarta.

Pakpahan, 1992. Kelembagaan Lahan dan Konservasi Tanah dan Air. PSE. Bogor.

Salim, H.S. 2003. Hukum Kontrak. Jakarta: Sinar Grafika.

Santoso, Urip. 2005. Hukum Agraria dan Hak-Hak Atas Tanah. Jakarta:Prenada Media.

Soekartawi, 1995. Analisis Usaha tani, UI Press, Jakarta.

Soekartawi, 2006. Analisis Usaha tani, UI Press, Jakarta.

Subekti. R dan Tjitrosudibio. 2003.

Kitab Undang-Undang HukumPerdata. Jakarta: Pradnya Paramita.

Sukardi. 2006. Penelitian Kualitatif Natralistik Pendidikan.Yogyakarta: Usaha Keluarga.

Wiranata, A.B I Gede. 2005. Hukum Adat Indonesia. Bandung: Citra Aditya Bakti 